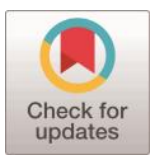

Article Type: Research Paper

\section{Islamic Financial Literacy and Financial Behavior: The case of Muhammadiyah Community in Medan City}

\author{
Ade Gunawan ${ }^{1 *}$, Asmuni ${ }^{2}$, and Saparuddin Siregar ${ }^{2}$
}

Abstract:

AFFILIATION:

${ }^{1}$ Department of Management, Faculty of Economics and Business, Universitas Muhammadiyah Sumatera Utara, North Sumatra, Indonesia

2 Department of Sharia Accounting, Faculty of Islamic Economics and Business, Universitas Islam Negeri Sumatera Utara, North Sumatra, Indonesia

\section{*CORRESPONDENCE:}

adegunawawan@umsu.ac.id

THIS ARTICLE IS AVAILABLE IN:

http://journal.umy.ac.id/index.php/ai

DOI: 10.18196/jai.v22i3.10043

\section{CITATION:}

Gunawan, A., Asmuni, A., \& Siregar, S. (2021). Islamic Financial Literacy and Financial Behavior: The case of Muhammadiyah Community in Medan City. Journal of Accounting and Investment, 22(3), 500-516.

\section{ARTICLE HISTORY}

\section{Received:}

22 Oct 2020

Revised:

26 Jan 2021

09 Mar 2021

04 May 2021

Accepted:

07 May 2021
Research aims: This study aims to determine and analyze the level of financial behavior, the level of Muhammadiyah community's Islamic financial literacy in Medan City, and the effect of Islamic financial literacy on financial behavior.

Design/Methodology/Approach: This research is descriptive quantitative using primary data through questionnaire. The research sample was 200 members of the Muhammadiyah organization in Medan City. The data analysis technique employed confirmatory factor analysis and structural equation modeling utilizing AMOS.

Research findings: The research confirmed that the level of Islamic financial knowledge among the Muhammadiyah community in Medan City was low, $60.56 \%$. In contrast to Islamic finance knowledge, the financial behavior of the Muhammadiyah community in Medan City was classified as good; $69.01 \%$ of the Muhammadiyah community showed relatively good financial behavior. These two things make the level of Islamic financial literacy among Muhammadiyah residents in Medan City classified as less literate. This shows that in everyday life, Muhammadiyah community in Medan City had good financial behavior but was more influenced by habits or finance. Meanwhile, as far as Sharia finance was concerned, the Muhammadiyah community in Medan City still did not understand it.

Theoretical contribution/Originality: This study provides information about the level of financial literacy and financial behavior of the Muhammadiyah community in Medan. This information becomes the basis for subsequent research to develop strategies to increase financial literacy and financial behavior of Muhammadiyah communities in Medan.

Practitioner/Policy implication: Since Muhammadiyah aims to improve the welfare of the people and various studies have shown a link between the level of financial literacy and one's welfare, Muhammadiyah organizers need to pay attention to this, such as organizing a more structured and systematic program to increase Muhammadiyah citizens' knowledge of Islamic finance.

Research limitation/Implication: This study still used a limited sample, namely Muhammadiyah communities. A broader sample will further confirm the validity of the literacy measurement instrument in the future.

Keywords: Financial Knowledge; Financial Literacy; Islamic Finance; Financial Behavior 


\author{
Gunawan, Asmuni, \& Siregar \\ Islamic Financial Literacy and Financial Behavior: ...
}

\title{
Introduction
}

While Islamic finance in Indonesia has enormous potential in Indonesians, it is well known that Indonesians have a low level of Islamic financial literacy, with only 37.72 percent compared to 75.28 percent for conventional finance. Financial inclusion in Islamic banks is 8.93 percent, while it is 9.10 percent in traditional banks. It means that only nine people out of every 100 use Sharia facilities. Even the Director of BSI acknowledges the low level of Islamic financial literacy, stating that the problem the Islamic financial institutions face today is that the level of Islamic financial inclusion is low, falling below $10 \%$ compared to traditional financial literacy. It impacts the decline in the potential of the Islamic financial market in Indonesia (Otoritas Jasa Keuangan, 2019).

It is proper for a Muslim to know, understand, and be willing to carry out all his life necessities in an Islamic manner, and one of them is to use Sharia financial facilities. Specifically, Muhammadiyah members are also part of the Muslim community in Indonesia. Muhammadiyah, one of the most prominent Islamic organizations in Indonesia with various business charities, has used Islamic banks in their financial transactions, such as monthly payroll. However, is this part of the supporting factors for the development of Islamic financial institutions in Indonesia? As one of the largest community groups in Indonesia, Muhammadiyah is undoubtedly part of the survey results. Nevertheless, do the survey results include the Muhammadiyah community members? Considering Muhammadiyah as a large institution that already has a constitution and a business unit that makes a major contribution to the nation's civilization, it certainly illustrates that Muhammadiyah citizens are a thriving group with a background of the possibility of having good financial behavior. Good financial behavior is an illustration that someone has the knowledge and ability to manage finances well because of the wise financial decisions in the use of their finances (Mitchell \& Lusardi, 2015).

The measurement of financial literacy itself cannot be related exclusively to the knowledge of products, organizations, and services, but there needs to be a focus on the ability reflected in the perception of the risks of financial decisions made. Therefore, measuring Islamic financial literacy must involve knowledge of financial behavior that accompanies the lives of Muhammadiyah members. Some previous studies have shown that in accordance with Shobah (2017) in his research, it is known that only $34 \%$ of customers were active as customers of Islamic banking, and the majority were only followers of the trend. Said and Amiruddin (2017) also stated that access to Islamic financial institutions was still low. In Jordan et al. (1999) found that 70 percent of Muslims chose to use Islamic financial services because it was in the interests of their religion, not because they fully knew the ins and outs of Islamic financial products. It shows the importance of understanding financial literacy in the life of Muslim communities.

On the other hand, as one of the big cities in Indonesia, Medan also has a large Muhammadiyah population (although the exact number is not known); considering a 
large number of charitable businesses, as many as 268 business units, it certainly illustrates that the population is quite large in Medan City (Muhammadiyah, 2021). However, how the level of Islamic financial literacy has not been described explicitly whether a large group of Muslim citizens has good knowledge and skills about Islamic financial institutions, and do all citizens use Islamic financial institutions? Are Muhammadiyah residents as Muslim citizens in Medan City already acting as active customers in Islamic banking?

For this reason, the authors conducted a research study on financial literacy and Islamic financial behavior in the Muhammadiyah community of Medan City. Since its establishment until now, Muhammadiyah has paid great attention to education and the family's economic welfare. Members of the organization, commonly referred to as Muhammadiyah members, follow the Islamic life guidelines, showing good exemplary behavior in their daily lives. Of course, it includes exemplary behavior; managing finances must be good. Muhammadiyah itself has an education and welfare program for its citizens, but has this program succeeded in supporting its citizens' financial literacy? As members of the Muhammadiyah organization in Medan City, the authors wanted to know how the financial behavior and level of Islamic financial literacy among Muhammadiyah residents in Medan City.

In general, the main problem raised in the research conducted is the measurement of financial literacy levels carried out in general with more emphasis on knowledge of products, institutions, and services. In fact, financial literacy places more emphasis on abilities, which involve understanding all the risks and consequences of decisions taken. Thus, the measurement tool (questionnaire) used could not only emphasize knowledge but also must involve decisions reflected in a person's behavior, which entirely reflects their financial literacy level.

Therefore, this study aimed to (1) identify and analyze Islamic financial behavior among members of Muhammadiyah organizations in Medan, (2) determine and analyze the level of Islamic financial literacy of Muhammadiyah organizational members in Medan, and (3) finding the effect of Islamic financial literacy on financial behavior.

\section{Literature Review and Hypothesis Development}

\section{Financial Literacy}

Financial literacy is the ability to read, analyze, organize, and communicate about financial conditions related to one's material well-being. Hung, Parker, and Yoong (2009) define financial literacy as the ability to use knowledge and skills in managing financial resources effectively for lifelong financial well-being. One basic knowledge of financial concepts is understanding how the concept of interest works, the difference between nominal and real value, and understanding risk diversification. Financial literacy is also defined as a person's ability to make simple decisions. For example, how one applies 
basic knowledge of the interest rules to decide on various debt contract options (Lusardi \& Mitchell, 2011; Lusardi \& Tufano, 2009).

Remund (2010) divides the concept of financial literacy into five categories: (1) Knowledge of financial concepts: so that individuals can manage their personal finances effectively; (2) Ability to communicate about financial concepts: a person's ability to communicate financial concepts and how to apply them; (3) Aptitude in managing personal finances: a person's ability to manage their income and obligations; (4) Skill in making appropriate financial decisions: Financial decisions are a major factor in financial literacy; and (5) Confidence to plan effectively for future financial needs: Doing effective financial planning for future needs. Meanwhile Chen and Volpe (1998) divided the measurement of financial literacy into four parts: (1) general knowledge about finance, including understanding the value of money; (2) savings and loans; (3) insurance; (4) investment; and (5) Measurement employed a questionnaire.

Table 1 Financial Literacy Level Category

\begin{tabular}{l|l|l|}
\hline \multicolumn{1}{c|}{ Category } & Value & \multicolumn{1}{c|}{ Information } \\
\hline Low & $<60 \%$ & It shows a low level of individual financial literacy. \\
Moderate & $60 \%-<80 \%$ & $\begin{array}{l}\text { It shows the level of individual financial literacy at the middle } \\
\text { level. }\end{array}$ \\
High & $\geq 80 \%$ & $\begin{array}{l}\text { It shows that the level of individual financial literacy is at a high } \\
\text { level. }\end{array}$ \\
\hline
\end{tabular}

Source: Chen and Volpe (1998, p.?)

Table 1 shows assessment of financial literacy level following Chen and Volpe (1998). The data describes the level of financial literacy for individual, which is $80 \%$ is the best level and uner $60 \%$ is un literate.

\section{Sharia Financial Literacy}

Taofik and Hamdani (2016) defined Islamic financial literacy as knowledge based on the Islamic financial system used to decide finance. Accordingly, this study defines Islamic financial knowledge as a person's ability to understand the basic concepts of finance, financial products, and services in managing financial resources effectively based on Sharia principles. This knowledge of finance includes aspects of general knowledge of finance, savings and loans, investment, insurance, and pawnshops based on the principles and rules used in Islam.

Table 2 Categorization of Islamic Financial Knowledge Levels

\begin{tabular}{lll}
\hline Category & Value & \multicolumn{1}{c}{ Information } \\
\hline High & $\geq 60 \%$ & $\begin{array}{l}\text { The level of knowledge of Islamic finance in individuals is at a high } \\
\text { level. }\end{array}$ \\
Low & $<60 \%$ & $\begin{array}{l}\text { The level of knowledge of Islamic finance in individuals is at a low } \\
\text { level. }\end{array}$ \\
\hline
\end{tabular}

Source: Antara, Musa, and Hassan (2016, p?) 
As shown in Table 2, it can be said that Sharia financial literacy is related to individual financial behavior. A person in his financial behavior is expected to differentiate products and services in conventional and Sharia banking and financing, Islamic and non-Sharia capital markets, and conventional and Sharia insurance products. Meanwhile, a person with a low level of Islamic financial literacy experiences difficulties in distinguishing conventional and Sharia financing, banking, capital market, and insurance products (Antara, Musa, \& Hassan, 2016).

\section{Financial Behavior}

Behavioral finance was recognized and developed by Professor Robert J. Shiller from Yale University in 1981. Another pioneer of behavioral finance is a professor of economics and behavioral science from the University of Chicago, Richard $\mathrm{H}$. Thaler. Financial behavior becomes a new way of thinking in understanding the phenomenon of the financial economy (Thaler, 2017). Financial treatment is a relatively new field of science. This theory is ready to replace the neoclassical theory as a paradigm that has been dominantly used to understand people's investing behavior in the current capitalist world. Financial behavior considers psychological and sociological factors as an essential foundation in making one's financial decisions. Thus, behavioral finance studies how psychology impacts financial decisions in households, markets, and organizations (Copur, 2015; Aprea et al., 2016).

Financial behavior theory is an application of psychology to the discipline of finance. Psychological factors influence an approach that explains how humans invest or deal with financial problems. Financial behavior results from psychological interactions with financial behavior and the performance of many investor categories, and the investors must be more careful in making investments so that decisions do not occur and are emotionally affected (Mankiw, 2003). Financial behavior is also a person's ability to manage day-to-day finances, including planning, budgeting, checking, managing, controlling, searching, and storing. The theory of financial management behavior develops from the amount of a person's desire to fulfill his/her needs according to the level of income earned (Kerlinger, 2002; Manurung, 2012).

\section{Financial Behavior Aspects}

Dew and Xiao (2011) explained several aspects of measuring financial behavior: (1) consumption, (2) cash flow, (3) savings and investment, and (4) credit management.

Table 3 Categorization of Financial Behavior Level

\begin{tabular}{lll}
\hline Category & Value & \\
\hline Good & $\geq 60 \%$ & The level of Islamic financial behavior in individuals is at a good level. \\
Deficient & $<60 \%$ & $\begin{array}{l}\text { The level of Islamic financial behavior in individuals is at a deficient } \\
\text { level. }\end{array}$ \\
\hline
\end{tabular}

As shown in Table 3, financial behavior is categorized by good behavior in a level of $60 \%$ above and deficient in a level of $60 \%$ below. 


\author{
Gunawan, Asmuni, \& Siregar \\ Islamic Financial Literacy and Financial Behavior: ...
}

\title{
Hypothesis Development
}

A person's ability to handle day-to-day finances, including preparing, budgeting, reviewing, handling, monitoring, searching, and storing, is referred to as financial behavior. Besides, a person with a low level of Islamic financial literacy experiences difficulties in distinguishing conventional and Sharia financing, banking, capital market, and insurance products (Antara et al., 2016; Manurung, 2012). The number of individuals who experience financial difficulties is not only due to low income but also because of errors in allocating income. Low levels of financial literacy led to inadequate income placement; therefore, having financial literacy intelligence will help make the right decisions. With good financial literacy, it will be able to make a good priority scale for the creation of a better future (Margaretha \& Sari, 2015). Based on the studies, the hypotheses determined in this study are:

$\boldsymbol{H}_{1}$ : Islamic financial literacy affects the Islamic financial behavior of Muhammadiyah organization members in Medan.

\section{Research Method}

This research is quantitative using deduction to test the level of Islamic financial literacy and how it impacts the financial behavior of Muhammadiyah members in Medan City. The study population was family's part of the Muhammadiyah organization members in Medan City. The total members were unknown, so that the sample taken was determined under the number of samples in the SEM analysis, namely 200 organization members randomly selected, who were Muhammadiyah families in Medan City. Ghozali (2013) recommends that the ideal number of samples to use SEM is in the range of 100 to 200 people to make a normal distribution of the data. Data were then analyzed: (1) The analysis of financial behavior of the Muhammadiyah organization members in Medan City, measured by information review, consumption, CFM, saving, investment, and loan. (2) The analysis of the level of Islamic financial literacy of Muhammadiyah members Medan city, assessed by general knowledge of finance, saving and loans, pawnshop, investment, and insurance. (3) The impact of Islamic financial literacy on financial behavior was also investigated. The data collection technique employed a questionnaire to measure financial knowledge and behavior. The survey was conducted in February 2020. The data analysis technique used a confirmatory test of factor analysis and structural equations utilizing AMOS since this method using a normal distribution of data, and the researchers could analyze it directly. This analysis is a multivariate statistical technique, a combination of factor analysis and regression analysis (correlation), intending to examine the relationship between variables in a model, both between indicators and their constructs, or the relationship between constructs, which can be done simultaneously and is more valid (Santoso, 2017). 


\section{Result and Discussion}

\section{Respondent Characteristic}

Research respondents were 142 people based on groups:

1. Gender and Occupation

Table 4 Distribution of Respondents by Gender and Occupation

\begin{tabular}{lcc}
\hline Occupation & Man (\%) & Woman (\%) \\
\hline Employee & 62.82 & 22.54 \\
Entrepreneurs & 11.97 & 0.00 \\
Retired & 0.00 & 3.52 \\
Homemakers & 0.00 & 45.07 \\
Not working & 1.41 & 0.00 \\
The others & 7.04 & 0.00 \\
Total (People) & 78 & 64 \\
\hline
\end{tabular}

Source: Primary data processed, 2020

As shown in Table 4, research respondents comprised 78 men (54.93\%) and 64 women $(45.07 \%)$. Most of the male respondents in this study worked as employees or professionals, as many as 49 people (62.82\%). Besides, 17 people (11.97\%) men worked as entrepreneurs. Meanwhile, 32 respondents (45.07\%) were homemakers. However, $22(22.54 \%)$ of the female respondents were registered as employees or professionals.

\section{Income and Expenses}

According to Table 5, it's known that the income of most respondents was more stable, both in terms of the amount received and the time of receipt of income. Total respondents with an income below the minimum wage were 96 people, with a breakdown of income between one million to three million rupiahs per month as many as 59 people (41.55\%) and below 1 million rupiahs per month as many as 37 people (26.06\%).

Table 5 Distribution of Respondents' Work Based on Income and Expenditures

\begin{tabular}{cccc|}
\hline Income & Percentage & Expenditures & Percentage \\
\hline$<1$ million & 26.06 & $<1$ million & 28.87 \\
1-3 million & 41.55 & $1-3$ million & 47.18 \\
3-6 million & 18.31 & $3-6$ million & 12.68 \\
$6-10$ million & 10.56 & $6-10$ million & 7.75 \\
$>10$ million & 3.52 & $>10$ million & 3.52 \\
\hline
\end{tabular}

\section{Age and Education Level}

As shown in Table 6, most of the respondents in this study were in the productive age, 26 people (18.31\%) in the age range $26-35$ years, 46 people $(32.39 \%)$ in the age range $36-45$ years, and 42 people (29.58\%) in the age range $46-55$ years. Most respondents 
also had a relatively high level of education; namely, 65 people $(45.77 \%)$ had completed the undergraduate education level, and 60 people (42.25\%) had completed the postgraduate/doctoral education level.

Table 6 Distribution of Respondents by Age and Education Level

\begin{tabular}{cccc|}
\hline Age & Percentage & Education & Percentage \\
\hline $15-25$ & $1.41 \%$ & Not school & 0.00 \\
$26-35$ & $18.31 \%$ & $\begin{array}{c}\text { Elementary school } \\
\text { and junior high school }\end{array}$ & 1.41 \\
& & Senior high school & 10.56 \\
$36-45$ & $32.39 \%$ & Undergraduate & 45.77 \\
$46-55$ & $29.58 \%$ & Postgraduate & 42.25 \\
\hline 55 & $18.31 \%$ & &
\end{tabular}

\section{Organization Membership}

As shown in Table 7, this study limited the research respondents to those active in Muhammadiyah and Aisiyah organizations for at least one year. One hundred eleven people $(78.17 \%)$ were already active in organizations over ten years. The remaining 31 people $(21.83 \%)$ were active in the organization within the range of 1-6 years.

Table 7 Distribution of Respondents by Organization Membership

\begin{tabular}{cc}
\hline Member & Percentage \\
\hline$<1$ year & 0.00 \\
$1-3$ years & 13.38 \\
$4-6$ years & 8.45 \\
$7-9$ years & 0.00 \\
$>10$ years & 78.17 \\
\hline
\end{tabular}

\section{Knowledge Level of Sharia Finance}

The descriptive analysis results of Islamic financial knowledge based on the dimensions measured in this research can be seen in the Table 8.

Table 8 Knowledge Level of Sharia Finance

\begin{tabular}{lcc}
\hline \multicolumn{1}{c}{ Category } & Good Knowledge & Low Knowledge \\
\hline General knowledge of finance (IFK-1) & 91 respondents & 51 respondents \\
Savings and Loans (IFK-2) & 57 respondents & 85 respondents \\
Pawnshop (IFK-3) & 48 respondents & 94 respondents \\
Investment (IFK-4) & 52 respondents & 90 respondents \\
Insurance (IFK-5) & 36 respondents & 106 respondents \\
Total & 56 respondents & 86 respondents \\
\hline
\end{tabular}

According to Table 8, the average Sharia finance knowledge of respondents in this study was low on knowledge related to savings, pawnshops, investments, insurance, and Islamic finance. However, knowledge related to general knowledge about finance, on average, the subject had higher knowledge. Of 56 respondents categorized as having a high level of knowledge of Islamic finance, in the dimension of general financial knowledge, 91 respondents were in the high category. However, in the dimensions of 
savings and loans, pawnshops, investment, and insurance, the rest respondents belonged to the low-level category of Islamic financial knowledge.

\section{Level of Islamic Financial Behavior}

The descriptive analysis results of financial behavior based on the dimensions measured in this research can be seen in Table 9.

Table 9 Financial Behavior Levels

\begin{tabular}{|c|c|c|}
\hline Category & Good & Deficient \\
\hline Information Review (IF) & 114 respondents & 28 respondents \\
\hline Consumption (CS) & 128 respondents & 14 respondents \\
\hline Cash-Flow Management (CFM) & 68 respondents & 74 respondents \\
\hline Savings (SV) & 114 respondents & 28 respondents \\
\hline Investment (IN) & 54 respondents & 88 respondents \\
\hline Loan (CM) & 90 respondents & 52 respondents \\
\hline Total & 98 respondents & 44 respondents \\
\hline
\end{tabular}

According to Table 9, there is a contrast to the Islamic finance knowledge, respondents in this study had diverse financial behaviors. The average respondents in this study showed good financial behavior. This sound financial behavior was particularly evident in keeping the information, saving, regulating consumption patterns, and managing credit. However, compared to the population average, the average respondents were still less capable of managing cash flow and investing. Based on the respondent's financial behavior, there were 98 respondents categorized as having good financial behavior out of 142 respondents. A total of 44 respondents were categorized as having poor financial behavior. In the dimension of analyzing information, consumption, savings, and loans, most respondents fell into the good category. The dimensions of cash flow management and investment fell into the unfavorable category, although the numbers were not too significant.

\section{Islamic Financial Literacy Level}

The descriptive analysis results of Islamic financial literacy in this study can be seen in Table 10.

Table 10 Islamic Financial Literacy Level

\begin{tabular}{lcc}
\hline Category & Frequency & Percentage (\%) \\
\hline Literate & 48 & 33.80 \\
Less Literate & 58 & 40.85 \\
Not Literate & 36 & 25.35 \\
\hline
\end{tabular}

As shown in Table 10, this study's level of Islamic financial literacy was seen from the interaction between the respondent's knowledge and behavior. As many as $33.80 \%$ of respondents were in the literate category, while $25,35 \%$ of the respondents were in the non-literate category. Table 10 displays that even though it was spread relatively even, $40.85 \%$ of the respondents were classified as less literate. In general, it could be 
concluded that the average respondent has shown that the respondents in this study had implemented behaviors related to Islamic finance well. However, this behavior was carried out without being based on good financial knowledge.

\section{The Measurement Results of Financial Behavior and Islamic Financial Literacy}

The measuring instrument in the form of a financial behavior research questionnaire built in this study consisted of six dimensions: information analysis (IF), consumption (CS), cash-flow management (CFM), savings (SV), investment (IN), and loans (CM). The Figure 1 shows of the model used to measure the validity test of financial behavior.

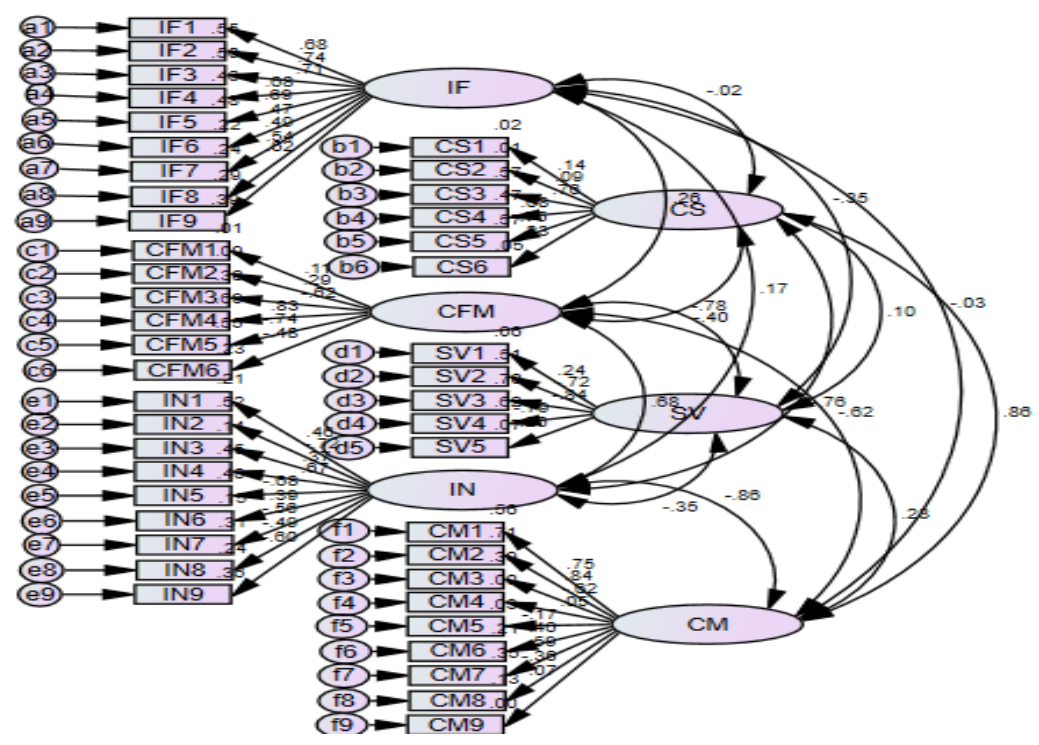

Figure 1 Validity Test of Islamic Financial Behavior

The data shows that most indicators (items) revealed good significance, as seen from the $p$-value $<0.05$. However, several items had a loading factor value below 0.50 . The following are the validity and reliability test results using variance extracted (AVE), construct reliability (CR), and discriminant validity (DV).

The test results uncovered that all dimensions of financial behavior were quite good (CR> 0.5) except for the CM dimension. Besides, the validity test results on all dimensions of financial behavior were quite good ( $D V>0.5$ ). Thus, the financial behavior questionnaire in this study could be utilized. Then, the categorization of the respondent's financial behavior was analyzed. There were 98 respondents categorized as having good financial behavior out of 142 respondents. Meanwhile, a total of 44 respondents were categorized as having poor financial behavior. In the dimension of analyzing information, consumption, savings, and loans, most respondents fell into the good category. In contrast, cash flow management and investment dimensions fell into the unfavorable category, although the numbers were not too significant. 


\section{Structural Equation Model Analysis}

The test in this study was carried out using a structural equation model analysis with the full equation model technique (complete structural equation model). This technique was used to test the research model and hypotheses developed in this study. The model used in this study is illustrated in the Figure 2.

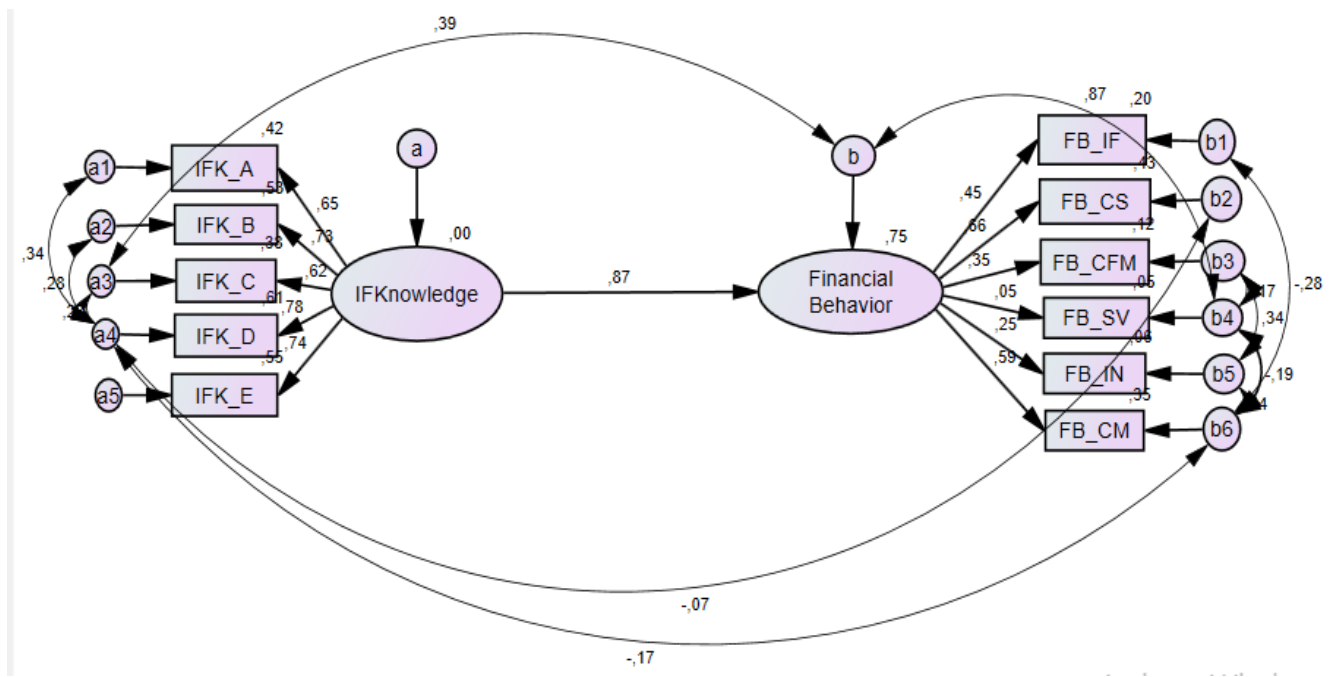

Figure 2 Inter-Variable Relationship Model

Further, the following are the goodness of fit feasibility test results after modifying the model.

Table 11 Feasibility Test Results for Modification of Goodness of Fit Model

\begin{tabular}{lccc}
\hline \multicolumn{1}{c}{ The Goodness of Fit Index } & Cut off Value & Outcome & Model Evaluation \\
\hline Chi-Square (df=31) & Estimate small & 43.701 & Good \\
CMIN/DF & $<2.00$ & 1.410 & Good \\
Sig. Probability & $>0.05$ & 0.065 & Good \\
GFI & $>0.90$ & 0.950 & Good \\
TLI & $>0.90$ & 0.956 & Good \\
CFI & $>0.90$ & 0.975 & Good \\
RMSEA & $<0.08$ & 0.054 & Good \\
\hline
\end{tabular}

As shown in Table 11, based on the goodness of fit feasibility test results after modifying the model, the overall evaluation of the model showed that the results were in a good range of values (fit).

\section{Results of Inter-Variable Influence Test}

The test for the influence between variables was carried out by looking at the results of regression weights. The results of the regression weight analysis test are shown in the Table 12. 
Table 12 Regression Weight Test Results for Estimated Value

\begin{tabular}{|c|c|c|c|c|c|c|}
\hline & & & Estimate & S.E. & C.R. & $P$ \\
\hline Financial Behavior & $<--$ & IFKnowledge & 0.866 & 0.478 & 4.384 & 0.000 \\
\hline FB_IF & $<---$ & Financial Behavior & 0.448 & 0.000 & 0.000 & 0.000 \\
\hline FB_CS & $<---$ & Financial Behavior & 0.657 & 0.172 & 4.792 & 0.000 \\
\hline FB_CFM & $<---$ & Financial Behavior & 0.350 & 0.116 & 3.108 & 0.002 \\
\hline FB_SV & $<---$ & Financial Behavior & 0.053 & 0.121 & 0.523 & 0.601 \\
\hline FB_IN & $<---$ & Financial Behavior & 0.246 & 0.175 & 2.513 & 0.012 \\
\hline FB_CM & $<---$ & Financial Behavior & 0.593 & 0.174 & 3.987 & 0.000 \\
\hline IFK_A & $<---$ & IFKnowledge & 0.651 & 0.000 & 0.000 & 0.000 \\
\hline IFK_B & $<---$ & IFKnowledge & 0.726 & 0.185 & 6.861 & 0.000 \\
\hline IFK_C & $<---$ & IFKnowledge & 0.617 & 0.168 & 5.739 & 0.000 \\
\hline IFK_D & $<---$ & IFKnowledge & 0.780 & 0.373 & 8.242 & 0.000 \\
\hline IFK_E & $<---$ & IFKnowledge & 0.744 & 0.165 & 6.747 & 0.000 \\
\hline
\end{tabular}

As shown in Table 12, based on the calculation results utilizing Structural Equation Modeling, Islamic financial knowledge significantly influenced financial behavior. The $\beta$ coefficient value of 0.866 illustrates a positive correlation. Meanwhile, the significance of the correlation could be seen from the C.R value of 3.446 . With a significance probability correlation smaller than the level of significance $(\alpha)$, determined by $5 \%(p=$ $0.000<0.05)$, it means that each 1 unit increase in Islamic financial knowledge would increase financial behavior by 0.866 units or $86.6 \%$.

\section{Discussion}

Islamic finance is selected as a subject of discussion because the contemporary Indonesian authorities are trying to grow the marketplace proportion of this industry. Hence, a deeper examination of this discipline is extraordinarily expected. In this case, the improvement of Islamic finance enterprise has been verified to assist monetary increase via the improvement of the actual sector of the country (Abduh \& Omar, 2012; Gheeraert \& Weill, 2015; Kassim, 2016).

In Islamic finance knowledge, the lowest research result was on the respondent's understanding of knowledge related to insurance; $74.65 \%$ of respondents in this study had a relatively low level of knowledge of insurance. The knowledge related to insurance used in this study included knowledge of the institutions supporting it, the objectives and benefits of insurance, the contracts and insurance rules applied in Islam, and Islamic insurance products and services in Indonesia.

The lack of knowledge about Sharia insurance is in line with research conducted by (Handayani \& Fathoni, 2019). Indonesian people in general already know about Sharia insurance products. However, this knowledge is limited to the knowledge that Islamic insurance does not contain usury and is far from gharar (obscurity). Meanwhile, the community lacked more detailed knowledge about Sharia insurance. Firli's (2017) research also disclosed that financial products, such as investment and insurance, tended to be more attractive to people with high/large incomes. It aligns with Maslow's hierarchy of needs theory. It is also in line with the findings of the Washington State 
University Social and Economic Sciences Research Center, which surveyed financial knowledge in Washington State in 2003. The survey explained that respondents who had been in college tended to have a higher level of financial knowledge than respondents who never sat in college. Lack of economic literacy and unawareness of this lack of know-how is listed in most of the not unusual place troubles of evolved and growing nations. In the research completed particularly in OECD nations and non-OECD nations, it found that people had a low stage of economic understanding even as making economic selections and that they are now no longer conscious of this low stage of understanding (Kılıç et al., 2015).

In contrast to the financial knowledge results on financial behavior, there were 98 people $(69.01 \%)$ of respondents in total in this study who showed good financial behavior, and $30.99 \%$ had a poor behavior level. This result is in accordance with the initial hypothesis proposed by the researchers that the financial behavior of the Muhammadiyah organization members in Medan was good. Financial behavior is a person's behavior in making financial decisions related to finding and reviewing information, consumption management, cash-flow management, saving and investment, and credit management in the past years.

On the other hand, the boom of economic literacy promotes progressed self-confidence, management, and independence (Alexander, et al., 2015); Conger et al. 1999). Good financial behavior could be seen in the behavior related to regulating consumption patterns by as much as $90.14 \%$ of respondents. As explained in the section on financial knowledge, the behavior regulating consumption patterns was directly affected by the income level. The effects are much like the ones of (Cude et al., 2006; Hilgert, Hogart, \& Beverly, 2003; Servon \& Kaestner, 2008) indicating that better economic expertise rankings affect better preferred economic behavior; similarly, humans with effective attitudes are extra susceptible to behave in a different constant way. However, the proof determined (Allen et al., 2007) has no longer been proved, wherein a correlation between economic expertise and economic mindset has been determined. It was concluded that the extent of economic literacy of college students had precedent the economic behavior, economic expertise, and economic mindset, with a better effect from mindset.

In this research, most respondents (62.82\%) worked as employees or professionals, which significantly influenced the consumption behavior of the respondents because the income received every month was relatively stable. In their research, Perry and Morris (2005) found that financial Knowledge and income influenced consumer financial behavior. This study was obtained from the analysis results of a diverse sample of people from society in America. The findings in this study also confirm the conceptual model regarding financial literacy (Hung et al., 2009). This model explains that financial literacy results from repeated interactions between financial knowledge, financial capability, one's perception of financial knowledge, and financial behavior. Financial knowledge is reflected in financial capabilities, a person's perception of financial knowledge and financial behavior. Financial behavior itself then provides a new financial knowledge and new perceptions of financial knowledge. This concept, according to the 
researchers, is equivalent to the concept of subjective knowledge and objective knowledge of Robb and Woodyard. Robb and Woodyard (2016) revealed that a person's subjective knowledge contributes majorly to a person's literacy level, shown from how financial decision making. This study's findings indirectly strengthen Robb and Woodyard's (2016) research.

It supports the experience of researchers who have been in the management of the North Sumatra Muhammadiyah Economic Council. The researchers found that in the Muhammadiyah organization, there were various economic empowerment programs, including MSMEs. Besides, there were also routine recitations that discussed various things, including Muamallah issues. At this recitation, it was not uncommon to discuss matters related to finance, including financial management. However, the assessments carried out were still relatively general in nature. Researchers have not seen a systematic curriculum or program to improve knowledge of Islamic finance for Muhammadiyah members. The researchers' observations found that the financial knowledge of Muhammadiyah members was obtained from their daily experiences and the educational institutions they lived in.

The results can be the basis for the need for guidance for Muhammadiyah Medan City to increase financial knowledge to have the solid financial literacy to make sound and wise financial decisions using their capital. This rise can be accomplished by solid financial education and training programs in daily financial management.

\section{Conclusion}

This study aimed to determine and analyze the levels of financial behavior and the Muhammadiyah community's Islamic financial literacy community in Medan City. Results showed that the knowledge level of Sharia finance for the Muhammadiyah community was low, namely $60.56 \%$. Muhammadiyah members were only high in finance knowledge, which included essential financial matters. Moreover, for other dimensions, over $50 \%$ of the knowledge level of Muhammadiyah members was low. Contrary to knowledge of Sharia finance, the financial behavior of Muhammadiyah members was classified as good. The results found that $69.01 \%$ of Muhammadiyah members uncovered relatively good financial behavior. The most prominent behavior was the ability of Muhammadiyah members to regulate consumption patterns. These two things make the Islamic financial literacy level of Muhammadiyah members classified as less literate. It indicates that Muhammadiyah members are already doing good financial behavior in daily life, but this behavior seems more influenced by habits or finance.

Meanwhile, in matters concerning Sharia finance, Muhammadiyah members still did not understand it. Therefore, it is expected that Muhammadiyah administrators pay attention to schedule, systematic education, and training programs to improve the financial knowledge of the Muhammadiyah community in Medan City. It is the basis for the need for guidance for the Muhammadiyah Medan City members in increasing 
financial knowledge, thus, having solid financial literacy to make sound and wise financial decisions by using their capital. Solid financial education and training programs can accomplish this rise in daily financial management. Nevertheless, this research only discussed the internal factor, such as knowledge measured by Islamic financial literacy and financial behavior. Thus, the subsequent research needs to do an exploratory study to explore external factors that have not been tested in this study but may be related to Islamic financial literacy and impact financial behavior. Location of residence (comparing in villages with cities), the use of social media, endowments, and other factors can influence behavior and financial knowledge.

\section{References}

Abduh, M., \& Azmi Omar, M. (2012). Islamic banking and economic growth: The Indonesian experience. International Journal of Islamic and Middle Eastern Finance and Management, 5(1), 35-47. https://doi.org/10.1108/17538391211216811

Alexander, A. T., Miller, K., \& Fielding, S. (2015). Open for business: Universities, entrepreneurial academics and open innovation. International Journal of Innovation Management, 19(6). https://doi.org/10.1142/s1363919615400137

Allen, M. W., Edwards, R., Hayhoe, C. R., \& Leach, L. (2007). Imagined interactions, family money management patterns and coalitions, and attitudes toward money and credit. Journal of Family and Economic Issues, 28(1), 3-22. https://doi.org/10.1007/s10834006-9048-1

Antara, P. M., Musa, R., \& Hassan, F. (2016). Bridging Islamic financial literacy and halal literacy: The way forward in halal ecosystem. Procedia Economics and Finance, 37, 196202. https://doi.org/10.1016/s2212-5671(16)30113-7

Aprea, C., Wuttke, E., Breuer, K., Koh, N. K., Davies, P., Greimel-Fuhrmann, B., \& Lopus, J. S. (2016). Financial literacy in the twenty-first century: An introduction to the international handbook of financial literacy. International Handbook of Financial Literacy, $1-4$.

Chen, H., \& Volpe, R. P. (1998). An analysis of personal financial literacy among college students. Financial Services Review, 7(2), 107-128. https://doi.org/10.1016/S1057$\underline{0810(99) 80006-7}$

Conger, R. D., Conger, K. J., Matthews, L. S., \& Elder, G. H. (1999). Pathways of economic influence on adolescent adjustment. American Journal of Community Psychology, 27(4), 519-541. https://doi.org/10.1023/a:1022133228206

Copur, Z. (Ed.). (2015). Handbook of Research on Behavioral Finance and Investment Strategies: Decision Making in the Financial Industry. IGI Global. http://doi:10.4018/978-1-46667484-4

Cude, B. J., Lawrence, F. C., Lyons, A. C., Metzger, K., LeJeune, E., Marks, L., \& Machtmes, K. (2006). College Students and financial literacy: What they know and what we need to learn. Eastern Family Economics and Resource Management Association, (January), 102-109.

Dew, J., \& Xiao, J. J. (2011). The financial management behavior scale: Development and validation. Journal of Financial Counseling and Planning, 22(1), 43-59. 
Firli, A. (2017). Factors that influence financial literacy: A conceptual framework. IOP Conference Series: Materials Science and Engineering, 180. https://doi.org/10.1088/1757$\underline{899 \mathrm{x} / 180 / 1 / 012254}$

Gheeraert, L., \& Weill, L. (2015). Does Islamic banking development favor macroeconomic efficiency? Evidence on the Islamic finance-growth nexus. Economic Modelling, 47, 32-39. https://doi.org/10.1016/i.econmod.2015.02.012

Ghozali, I. (2013). Desain penelitian kuantitatif \& kualitatif untuk akuntansi, bisnis dan ilmu sosial lainnya $(V)$. Semarang: Badan penerbit Universitas Diponegoro.

Handayani, T., \& Fathoni, M. A. (2019). Persepsi masyarakat terhadap asuransi syariah. Conference on Islamic Management, Accounting, and Economics (CIMAE) Proceeding, 2, 127132. Retrieved from https://journal.uii.ac.id/CIMAE/article/view/12757

Hilgert, M.A., Hogart, J.M., \& Beverly, S.G. (2003). Household financial management: The connection between knowledge and behavior. Federal Reserve Bulletin, 309-322. Retrieved from https://www.federalreserve.gov/pubs/bulletin/2003/0703lead.pdf

Hung, A., Parker, A. M., \& Yoong, J. (2009). Defining and Measuring Financial Literacy. RAND Working Paper Series WR-708. https://dx.doi.org/10.2139/ssrn.1498674

Kassim, S. (2016). Islamic finance and economic growth: The Malaysian experience. Global Finance Journal, 30, 66-76. https://doi.org/10.1016/i.gfj.2015.11.007

Kerlinger, F. N. (2002). Azas-azas penelitian behavioral. Yogyakarta: Gajah Mada University Press.

Kılıç, Y., Ata, H. A., \& Seyrek, I.H. (2015). Financial literacy: A study of university students. Journal of Accounting and Finance, April (66), 129-150. https://doi.org/10.25095/mufad.396535

Lusardi, A., \& Mitchell, O. S. (2011). Financial literacy around the world: an overview. Journal of Pension Economics and Finance, 10(4), 497-508. https://doi.org/10.1017/s1474747211000448

Lusardi, A., \& Tufano, P. (2009). Debt literacy, financial experience, and overindebtedness. NBER Working Paper Series. Retrieved from http://www.nber.org/papers/w14808

Mankiw, N.G. (2003). Teori Makro Ekonomi. Jakarta: Gramedia Pustaka.

Manurung, A. H. (2012). Teori perilaku keuangan (Behaviour finance). Economis of Management, 41(4), 1-13.

Margaretha, F., \& Sari, S. (2016). Faktor penentu tingkat literasi keuangan para pengguna kartu kredit di Indonesia. Journal of Accounting and Investment, 16(2), 132-144. https://doi.org/10.18196/jai.2015.0038.132-144

Mitchell, O. S., \& Lusardi, A. (2015). Financial literacy and economic outcomes: Evidence and policy implications. The Journal of Retirement, 3(1), 107-114. https://doi.org/10.3905/jor.2015.3.1.107

Naser, K., Jamal, A., \& Khatib, K. (1999). Islamic banking: A study of customer satisfaction and preferences in Jordan. International Journal Of Banking Marketing, 17(3), 135-150. Retrieved from http://www.emeraldinsight.com/doi/pdfplus/10.1108/02652329910269275

Otoritas Jasa Keuangan. (2019). Laporan perkembangan keuangan syariah Indonesia 2019: Sinergi dalam membangun ekosistem ekonomi dan keuangan syariah. Retrieved from https://ojk.go.id/id/kanal/syariah/data-dan-statistik/laporan-perkembangankeuangan-syariahindonesia/Documents/LAPORAN\%20PERKEMBANGAN\%20KEUANGAN\% 20SYARIAH $\% 20$ INDONESIA $\% 202019$.pdf 
Perry, V. G., \& Morris, M. D. (2005). Who is in control? The role of self-perception, knowledge, and income in explaining consumer financial behavior. Journal of Consumer Affairs, 39(2), 299-313. https://doi.org/10.1111/j.1745-6606.2005.00016.x

Remund, D. L. (2010). Financial literacy explicated: The case for a clearer definition in an increasingly complex economy. Joumal of Consumer Affairs, 44(2), 276-295. https://doi.org/10.1111/j.1745-6606.2010.01169.x

Robb, C. A., \& Woodyard, A. S. (2011). Financial knowledge and best practice behavior. Journal of Financial Counseling and Planning, 22(1), 60-70.

Said, S., \& Amiruddin, A. M. A. (2017). Literasi keuangan syariah di perguruan tinggi keagamaan Islam (Studi kasus UIN Alauddin Makasar). Jurnal Studi Islam Al-Ulum, 17(1). https://doi.org/10.30603/au.v17i1.29

Santoso, S. (2017). Menguasai statistik dengan SPSS 24. Jakarta: PT. Alex Media Komputindo.

Servon, L. J., \& Kaestner, R. (2008). Consumer financial literacy and the impact of online banking on the financial behavior of lower-income bank customers. Journal of Consumer Affairs, 42(2), 271-305. https://doi.org/10.1111/j.1745-6606.2008.00108.x

Shobah, N. (2017). Analisis literasi keuangan syariah terhadap penggunaan jasa perbankan syariah sebagai upaya meningkatkan sharia financial inclusion (Studi pada Mahasiswa Ekonomi Syariah UIN Sunan Ampel Surabaya. Undergraduate Thesis. Universitas Islam Negeri Sunan Ampel Surabaya.

Taofik, H., \& Hamdani, M. (2016). Measuring Islamic financial literacy. The $2^{\text {nd }}$ International Research Conference on Business and Economics (IRCBE), 1-4.

Thaler, R. H. (2017). Integrating economics with psychology. The Royal Swedish Academy of Sciences, 1-37. Retrieved from https://www.nobelprize.org/uploads/2018/06/advancedeconomicsciences2017.pdf 